\title{
Pengaruh Berbagai Indeks Saham Asia terhadap Indeks Harga Saham Gabungan Tahun 2015-2019
}

\author{
Vincent Hartantio dan Yusbardini \\ Program Studi Sarjana Manajemen Fakultas Ekonomi \\ Universitas Tarumanagara \\ Email: vincenthartan@gmail.com
}

\begin{abstract}
The purpose of this study is to analyze the effect of Nikkei 225 Index, Strait Times Index, Kuala Lumpur Composite Index, Hang Seng Index and Korean Composite Stock Price Index against Jakarta Composite Index (JCI) during the observed period from 2015-2019. The analytical method used in this study are unit root test, classic assumption test,cointegration test and multiple regression analysis performed with E-views 9.0. This research used monthly data from 2015 - 2019 for each variable. This research analyzing the influence of Nikkei 225 Index, Strait Times Index, Kuala Lumpur Composite Index, Hang Seng Index and Korean Composite Stock Price Index toward Jakarta Composite Index simultaneously and partially. The result of the study shows that simultaneously Nikkei 225 Index, Strait Times Index, Kuala Lumpur Composite Index, Hang Seng Index and Korean Composite Stock Price Index has significant effect on Jakarta Composite Index.
\end{abstract}

Keywords: Nikkei 225 Index, Strait Times Index, Kuala Lumpur Composite Index, Hang Seng Index and Korean Composite Stock Price Index, Jakarta Composite Index (JCI)

Abstrak: Tujuan penelitian ini adalah untuk mengetahui pengaruh dari Indeks Nikkei 225, Strait Times Index, Kuala Lumpur Composite Index (KLCI), Indeks Hang Seng, Korean Composite Stock Price Index (KOSPI) terhadap Indeks Harga Saham Gabungan pada periode 2015-2019. Metode analisis yang digunakan dalam penelitian ini adalah uji akar unit, uji asumsi klasik, uji kointegrasi, dan uji analisis regresi berganda yang menggunakan program E-views 9.0. Penelitian ini menggunakan data bulanan pada periode tahun 2015-2019 untuk setiap variabelnya. Penelitian ini menganalisi pengaruh Indeks Nikkei 225, Strait Times Index, Kuala Lumpur Composite Index (KLCI), Indeks Hang Seng, Korean Composite Stock Price Index (KOSPI) terhadap Indeks Harga Saham Gabungan secara bersama-sama dan sebagian. Hasil dari penelitian ini menunjukan bahwa pengaruh Indeks Nikkei 225, Strait Times Index, Kuala Lumpur Composite Index (KLCI), Indeks Hang Seng, Korean Composite Stock Price Index (KOSPI) saling mempengaruhi secara signifikan.

Kata kunci: Indeks Nikkei 225, Strait Times Index, Kuala Lumpur Composite Index (KLCI), Indeks Hang Seng, Korean Composite Stock Price Index (KOSPI), Indeks Harga Saham Gabungan.

\section{LATAR BELAKANG}

Pasar modal merupakan peranan yang penting bagi perekonomian negara karena pasar modal memiliki dua fungsi, yaitu pertama sebagai sarana bagi pendanaan usaha dan sebagai sarana bagi pendanaan perusahaan untuk mendapatkan dana dari masyarakat, dana yang diperoleh dari pasar modal dapat digunakan untuk pengembangan usaha, penambahan modal kerja, meningkatkan kinerja perusahaan dan lain-lain. Fungsi yang kedua dari pasar modal adalah sebagai sarana investasi masyarakat pada instrumen keuangan seperti saham, obligasi, reksadana dan lain-lain. 
Investasi adalah menempatkan uang atau dana dengan harapan untuk memperoleh tambahan atau keuntungan tertentu atas uang atau dana tersebut. (Ahmad, 1996). Uang atau dana yang di investasi-kan dapat berupa saham, obligasi, reksadana, dan lainnya. Individu yang melakukan segala jenis bentuk investasi disebut investor. Tujuan investor melakukan kegiatan investasi yaitu untuk mencari atau memperoleh pendapatan atau tingkat pengembalian investasi (return) yang akan diterima di masa depan (Puspitaningtyas dan Kurniawan, 2012).

Menurut Sutrisno (2012:5), pengambilan keputusan investasi merupakan bagaimana manajer keuangan bisa mengalokasikan dana perusahaan ke dalam bentuk investasi yang akan mendatangkan keuntungan di masa depan. Investor harus berfikir rasional untuk dapat mengambil keputusan investasi yang baik dengan cara mempertimbangkan segala laba dan risiko yang diterima. Investor dapat membandingkan jnis investasi yang akan dipilih berdasarkan informasi akuntansi dan laporan keuangan suatu perusahaan. Namun, karena investasi merupakan sesuatu hal yang selalu tidak pasti, maka investor seringkali berfikir secara irasional dalam mengambil keputusan investasi.

Indeks harga saham gabungan merupakan indeks yang menggunakan semua emiten di Bursa Efek Indonesia (BEI) untuk dijadikan sebagai komponen dalam perhitungan indeks harga. Di samping itu, Bursa Efek Indonesia memiliki hak untuk memasukkan dan mengeluarkan beberapa emiten/perusahaan yang tercatat supaya bisa menunjukkan keadaan di pasar modal yang wajar. Indeks saham IHSG atau biasanya disebut sebagai Jakarta Composite Index (JCI) ini dibentuk pertama kali pada tanggal 1 April 1983 sebagai indikator adanya pergerakan dan perubahan harga saham di BEI. Namun, kenaikan dan penurunan IHSG bukan mengindikasikan bahwa semua harga saham di BEI mengalami kenaikan atau penurunan. Alasannya adalah karena apabila IHSG naik, maka sebagian besar harga saham yang tercatat di bursa cenderung naik daripada harga saham yang sedang mengalami penurunan dan sebaliknya..

Indeks saham merupakan sebuah indikator yang dapat dijadikan suatu gambaran terkait dengan besar kecilnya suatu perubahan harga pada pasar saham dalam kurun waktu tertentu. Dengan adanya serangkaian perhitungan yang menggabungkan metodologi perhitungan indeks dengan pilihan instrumen pasar modal serta keuangan, bermacam jenis indeks saham BEI diharapkan mampu menyediakan investor pandangan serta gambaran akurat mengenai kondisi serta arah pergerakan pasar yang aktual.

Sebagai komponen penting untuk memantau pergerakan harga sama di bursa, IHSG memiliki dua fungsi utama bagi investor. Pertama sebagai representasi dari perkembangan harga saham secara umum, Indeks Harga Saham Gabungan (IHSG) adalah nilai representatif dari semua harga saham yang tercatat di BEI. Oleh karena itu, IHSG dapat dimanfaatkan oleh investor untuk memantau pergerakan serta perkembangan harga saham di Indonesia dari mulai IHSG dihitung. Kedua sebagai acuan untuk portofolio, fungsi lain dari IHSG adalah dapat dijadikan sebagai acuan dalam portofolio saham. Ketika IHSG bergerak lebih tinggi daripada kenaikan harga saham portofolio saham investor, maka kinerja dari portofolio saham tersebut sedang memburuk dan sebaliknya.

\section{KAJIAN TEORI}

Teori random walk atau disebut juga random walk hypothesis muncul tahun 1973. Saat itu, Burton G.Malkiel, dosen ekonomi Universitas Princeton, menulis buku bertajuk A Random Walk Down Wall Street. Random walk adalah teori pasar saham yang mengatakan bahwa harga saham di masa lampau serta arah harga saham atau pasar secara keseluruhan tidak bisa dipakai sebagai alat untuk meramal pergerakan harga saham di masa mendatang. 
Sebab, harga saham bergerak secara acak (random) dan tak bisa diprediksi. Peluangnya untuk naik sama dengan peluangnya untuk turun. Tapi, jangka panjang, harga saham akan cenderung meningkat.

Menurut Husted, et al. (2010:398), contagion effect menyebabkan krisis di suatu negara menular ke negara lainnya. Menurut beberapa ahli berpendapat bahwa keadaan perekonomian suatu negara akan berpengaruh terhadap kondisi perekonomian negara lain. Kondisi krisis negara - negara Asia tahun 1997 terutama disebabkan oleh adanya contagion effect (domino effect) dari negara lain (Tan Jose Antonio, 1998). Indonesia sebagai salah satu negara berkembang sangat tergantung pada kondisi perekonomian luar negeri, terutama yang berkaitan dengan investasi. Akibatnya, kondisi pasar modal di Indonesia diduga dipengaruhi oleh kondisi luar negeri terutama kondisi pasar modal yang ada pada negara-negara maju.

Pengaruh Indeks Nikkei 225 Terhadap IHSG. Sebagai salah satu negara tujuan ekspor Indonesia, pertumbuhan ekonomi Jepang dapat mendorong pertumbuhan ekonomi Indonesia melalui kegiatan ekspor maupun aliran modal masuk, baik investasi langsung maupun melalui pasar modal (Sunariyah,2006). Yuono (2011) menjelaskan bahwa keterkaitan antara Jepang dan Indonesia dapat dikatakan sangat kuat. Hasil penelitian yang dilakukan oleh Witjaksono (2010) menunjukkan bahwa Indeks Nikkei 225 berpengaruh positif dan signifikan terhadap IHSG.

Pengaruh Strait Times Index Terhadap IHSG. Singapura merupakan sumber investor luar negeri teratas bagi Indonesia, Indonesia merupakan mitra dagang terbesar kedua Singapura di antara negara-negara anggota ASEAN. Sehingga, keadaan ekonomi Singapura akan berpengaruh terhadap keadaan ekonomi Indonesia. Nurul Hidayah (2012) menyatakan bahwa Strait Times Index memiliki pengaruh yang signifikan terhadap IHSG

Pengaruh Indeks KLCI Terhadap IHSG. Malaysia merupakan negara yang secara geografis berdekatan dengan Indonesia. Menurut Moh. Mansur (2005), kejadian dan dinamika harga saham di satu bursa dapat mempengaruhi bursa yang lain terutama dengan bursa dari negara-negara yang berdekatan. Para ahli berpendapat bahwa kondisi perekonomian suatu negara lain akan berpengaruh terhadap kondisi perekonomian negara. Indonesia sebagai salah satu negara berkembang hingga saat ini masih sangat tergantung pada kondisi perekonomian luar negeri terutama yang berkaitan dengan investasi. Akibatnya, kondisi pasar modal di Indonesia dipengaruhi oleh kondisi luar negeri terutama kondisi pasar modal negara-negara lain.

Pengaruh Indeks Hang Seng Terhadap IHSG. Hang Seng Index (HSI) adalah indeks kumulatif dari 50 saham blue chip dari Hongkong Stock Market, yang merupakan salah satu index saham terpercaya, yang digunakan para investor dan fund manager untuk berinvestasi. Saham-saham yang yang terdaftar di dalam indeks ini berasal dari berbagai sektor, seperti Industri, Finance, Properti dan sebagainya. Bursa saham Hongkong menempati posisi sebagai bursa saham terbesar kedua di Asia. Oleh karena itu, bursa saham Hongkong lebih banyak diminati oleh para investor. Dengan demikian, adanya perubahan harga pada indeks Hang Seng akan berpengaruh pada pergerakan IHSG di BEI.

Pengaruh Indeks KOSPI Terhadap IHSG. KOSPI 200 diperdagangkan bersama Option di bursa berjangka index saham Korea Selatan, pada divisi Korea Stock Exchange (KSE). Salah-satu instrumen investasi yang paling diminati oleh para investor dalam negeri Korea itu sendiri, maupun investor Indonesia dan investor internasional lainnya, dengan kontribusi sebesar $10 \%$ dari total transaksi, setelah Nikkei dan Hang Seng. Namun berbeda dengan 
Hang Seng dan Nikkei, KOSPI mempunyai korelasi yang lebih tinggi terhadap pasar Asia dibandingkan dengan pasar Amerika.

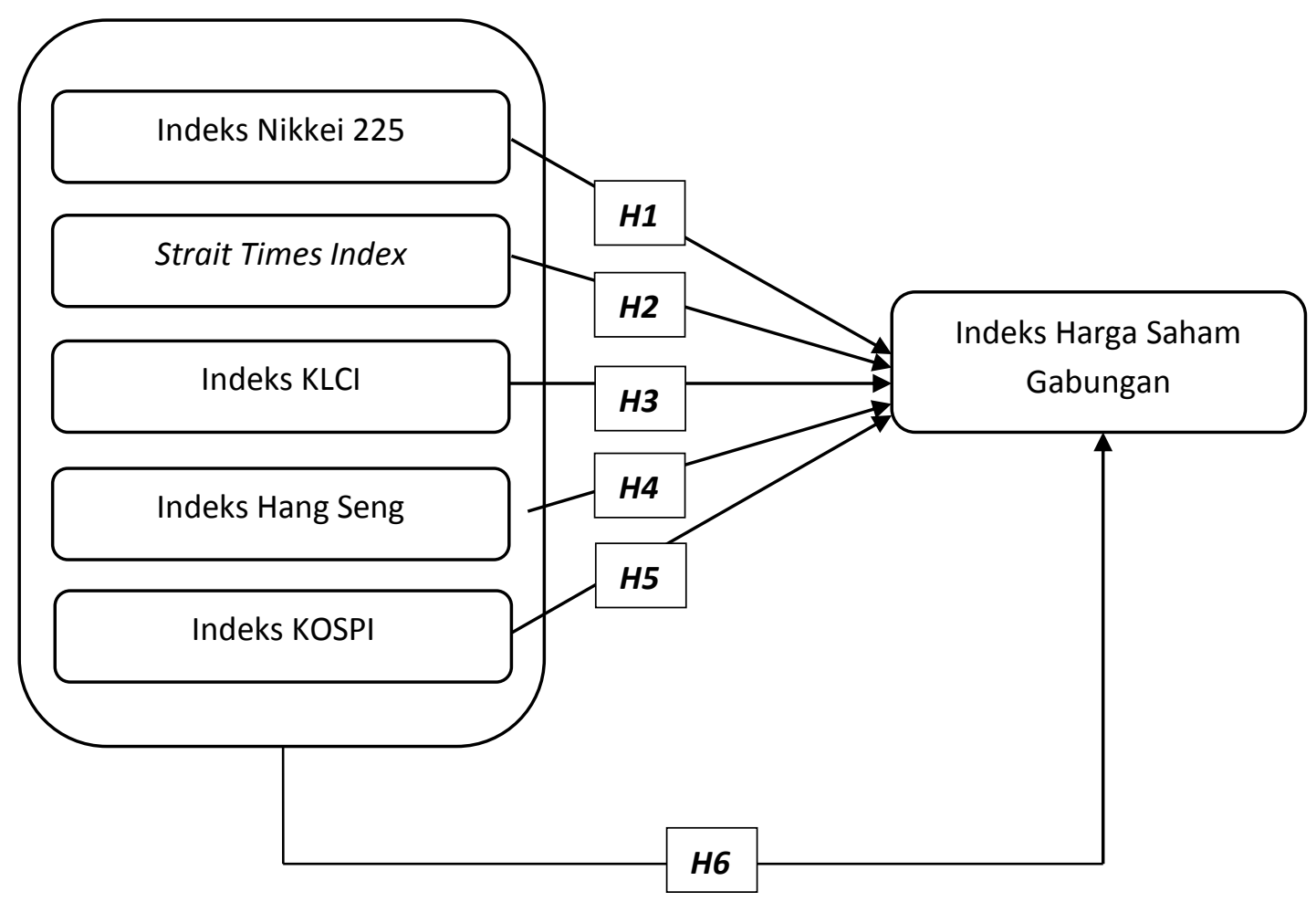

Gambar 1. Kerangka Pemikiran

Berdasarkan kerangka pemikiran diatas, hipotesis yang digunakan dalam penelitian ini adalah sebagai berikut:

H1: Terdapat pengaruh dari indeks Nikkei 225 terhadap Indeks Harga Saham Gabungan pada tahun 2015 - 2019 .

H2: Terdapat pengaruh dari Strait Times Index terhadap Indeks Harga Saham Gabungan pada tahun 2015 - 2019.

H3: Terdapat pengaruh dari indeks KLCI terhadap Indeks Harga Saham Gabungan pada tahun $2015-2019$.

H4: Terdapat pengaruh dari indeks Hang Seng terhadap Indeks Harga Saham Gabungan pada tahun 2015 - 2019.

H5: Terdapat pengaruh dari indeks KOSPI terhadap Indeks Harga Saham Gabungan pada tahun $2015-2019$.

H6: Terdapat pengaruh secara bersama-sama dari indeks Nikkei 225, Strait Times Index, indeks KLCI, indeks Hang Seng, indeks KOSPI terhadap Indeks Harga Saham Gabungan pada tahun 2015 - 2019.

\section{METODOLOGI}

Metode yang akan digunakan untuk memilih sampel pada penelitian ini yaitu dengan metode non probabilitas dimana setiap unsur populasi tidak mempunyai peluang yang sama untuk dijadikan sebagai anggota sampel dan menggunakan teknik non probability sampling yang berbasis Quota Sampling. Penulis menggunakan penelitian time series, yaitu data yang 
dikumpulkan untuk memberikan gambaran tentang perkembangan suatu kegiatan dari periode tertentu. Kasus yang diteliti dalam penelitian ini adalah indeks Nikkei 225, Strait Times Index, indeks KLCI, indeks Hang Seng, indeks KOSPI terhadap Indeks Harga Saham Gabungan pada tahun 2015-2019. Sampel yang digunakan sebanyak 5 Indeks saham dari berbagai macam indeks saham di ASIA. Data yang digunakan dalam penelitian ini adalah data sekunder yang diperoleh dari yahoo.finance.com dan investing.com

Penelitian ini terdiri dari variabel independen dan dependen. Variabel independen merupakan variabel yang dapat mempengaruhi suatu model namun nilainya tidak dapat dipengaruhi oleh model tersebut. Sedangkan variabel dependen merupakan variabel yang nilainya dipengaruhi oleh variabel independen dalam suatu model. Pada penelitian ini terdapat 5 variabel independen, yakni indeks Nikkei 225, Strait Times Index, indeks KLCI, indeks Hang Seng, indeks KOSPI, serta 1 variabel dependen yakni Indeks Harga Saham Gabungan

Penelitian ini menggunakan software E-views 9.0. Dalam pengujian ini terdapat uji statistic deskriptif, uji stastioneritas, uji derajat integrasi, uji asumsi klasik, uji kointegrasi, analisis regresi berganda.

\section{HASIL UJI STATISTIK}

Penelitian ini dilakukan dengan bertahap, yakni uji awal dan uji akhir.

Tabel 1. Hasil Uji E-views 9.0

\begin{tabular}{|l|c|c|c|c|c|c|}
\hline & IHSG & NIKKEI 225 & STI & KLCl & HSI & KOSPI \\
\hline Mean & 5628.694 & 20123.68 & 3153.988 & 1708.407 & 25715.20 & 2152.678 \\
\hline Median & 5814.475 & 20134.58 & 3206.660 & 1692.005 & 25968.99 & 2085.720 \\
\hline Maximum & 6605.630 & 24120.04 & 3613.930 & 1870.370 & 32887.27 & 2566.460 \\
\hline Minimum & 4223.910 & 15575.92 & 2629.110 & 1561.740 & 19111.93 & 1912.060 \\
\hline Std. Dev. & 641.6176 & 2172.473 & 238.5829 & 77.24313 & 3243.770 & 183.5233 \\
\hline Skewness & -0.384900 & -0.233386 & -0.298056 & 0.380652 & -0.117505 & 0.714206 \\
\hline Kurtosis & 2.069158 & 2.113370 & 2.162973 & 2.359692 & 2.141000 & 2.197626 \\
\hline & & & & & & \\
\hline Jarque-Bera & 3.647647 & 2.509972 & 2.639909 & 2.473945 & 1.982776 & 6.710418 \\
\hline Probability & 0.161407 & 0.285080 & 0.267147 & 0.290262 & 0.371061 & 0.034902 \\
\hline & & & & & & \\
\hline Sum & 337721.6 & 1207421. & 189239.3 & 102504.4 & 1542912. & 129160.7 \\
\hline $\begin{array}{l}\text { Sum Sq. } \\
\text { Dev. }\end{array}$ & 24288717 & $2.78 \mathrm{E}+08$ & 3358386. & 352023.5 & $6.21 \mathrm{E}+08$ & 1987168. \\
\hline & & & & & & 60 \\
\hline Observations & 60 & 60 & 60 & 60 & 60 & 60 \\
\hline
\end{tabular}

Gambar 2 menunjukan hasil dari analisis statistik deskriptif pada keseluruhan variabel meliputi Indeks Nikkei 225 (NIKKEI 225), Strait Times Index (STI), Indeks KLCI (KLCI), Indeks Hang Seng (HIS), dan Indeks KOSPI (KOSPI). Yang dijadikan sampel penelitian selama periode 2015-2019.

Tabel 2. Hasil Uji T,F,R 


\begin{tabular}{|c|c|c|c|}
\hline Variabel & $\begin{array}{c}\text { Uji t (Parsial) } \\
\text { Prob (t-statistic) }\end{array}$ & $\begin{array}{c}\text { Uji F (Simultan) } \\
\text { Prob (F-statistic) }\end{array}$ & $\begin{array}{c}\text { Uji R-squared } \\
\left(\mathrm{R}^{2}\right)\end{array}$ \\
\cline { 1 - 2 } Indeks Nikkei 225 & 0.9684 & & \\
\cline { 1 - 2 } Strait Times Index & 0.7378 & \multirow{2}{*}{0,003792} & 0.273623 \\
\cline { 1 - 2 } Indeks KLCI & 0.0111 & & \\
\cline { 1 - 2 } Indeks Hang Seng & 0.3381 & & \\
\cline { 1 - 2 } Indeks KOSPI & 0.9358 & & \\
\hline
\end{tabular}

\section{Uji Koefisien Determinasi $\left(\mathbf{R}^{2}\right)$}

Nilai dari koefisien determinasi $\left(\mathrm{R}^{2}\right)$ menunjukkan besarnya kontribusi dari variabel independen overconfidence, representativeness bias, dan risk tolerance terhadap pengambilan keputusan investasi.

Tabel 3. Hasil Uji $\mathrm{R}^{2}$

\begin{tabular}{|c|c|}
\hline Variabel & $\mathbf{R}^{\mathbf{2}}$ \\
\hline Indeks Harga Saham Gabungan & 0,273623 \\
\hline
\end{tabular}

Dari tabel 3 dapat terlihat bahwa presentase besarnya Indeks Harga Saham Gabungan yang dapat dijelaskan oleh Indeks Nikkei 225, Strait Times Index, Indeks KLCI, Indeks HangSeng, Indeks KOSPI sebesar 27,3623\%

\section{Uji Hipotesis}

Tujuan dari uji ini adalah untuk menguji apakah terdapat pengaruh yang signifikan dari suatu variabel independen terhadap variabel dependen. Jika probabilitias indeks $>0,05$ maka tidak terdapat pengaruh yang signifikan antara indeks-indeks terhadap indeks harga saham gabungan. Jika probabilitias indeks $<0,05$ maka terdapat pengaruh yang signifikan antara indeks-indeks terhadap indeks harga saham gabungan Hasil dari pengujian disajikan dalam tabel di bawah ini

Tabel 4. Hasil Uji T

\begin{tabular}{|c|c|}
\hline Variabel & Uji t (Parsial) Prob (t-statistic) \\
\hline Indeks Nikkei 225 & 0.9684 \\
\hline Strait Times Index & 0.7378 \\
\hline Indeks KLCI & 0.0111 \\
\hline Indeks Hang Seng & 0.3381 \\
\hline Indeks KOSPI & 0.9358 \\
\hline
\end{tabular}

Nilai t-statistics ditujukan untuk menguji hipotesis penelitian, jika nilai > 0,05 maka tidak terdapat pengaruh yang signifikan, jika nilai $<0,05$ maka terdapat pengaruh yang signifikan.

Berdasarkan hasil nilai $\mathrm{T}$ yang diperoleh tersebut, dapat dinyatakan bahwa:

1. Indeks Nikkei 225 tidak terdapat pengaruh yang signifikan

Terhadap Indeks Harga Saham Gabungan

2. Strait Times Index tidak terdapat pengaruh yang signifikan

Terhadap Indeks Harga Saham Gabungan

3. Indeks KLCI terdapat pengaruh yang signifikan 
Terhadap Indeks Harga Saham Gabungan

4. Indeks Hang Seng tidak terdapat pengaruh yang signifikan

Terhadap Indeks Harga Saham Gabungan

5. Indeks KOSPI tidak terdapat pengaruh yang signifikan

Terhadap Indeks Harga Saham Gabungan

\section{DISKUSI}

\section{Pengaruh Indeks Nikkei 225 terhadap IHSG}

Berdasarkan hasil analisi data yang dilakukan oleh peneliti, diketahui bahwa indeks Nikkei 225 berpengaruh negatif dan tidak signifikan terhadap Indeks Harga Saham Gabungan. Hasil ini sesuai dengan penelitian yang dilakukan oleh Wijayanti (2013) yang menyatakan bahwa tidak terdapat pengaruh yang signifikan antara indeks Nikkei 225 terhadap Indeks Harga Saham Gabungan. Setiap 1 poin kenaikan N225 akan direspon melemahnya IHSG dalam jangka pendek, dan dalam jangka panjang. Krisis global dan bencana alam menyebabkan pertumbuhan ekonomi Jepang dibawah Indonesia sehingga investor tidak terlalu memperhatikan kondisi bursa Jepang.

\section{Pengaruh Strait Times Index terhadap IHSG}

Berdasarkan hasil analisi data yang dilakukan oleh peneliti, diketahui bahwa Strait Times Index berpengaruh positif dan tidak signifikan terhadap Indeks Harga Saham Gabungan. Hasil ini sesuai dengan penelitian yang dilakukan oleh Ahmad Sidiq (2010) yang menyatakan bahwa terdapat pengaruh yang signifikan antara Strait Times Index terhadap Indeks Harga Saham Gabungan. Nilai tukar dan harga saham global berpengaruh terhadap pergerakan saham, secara bersama-sama indeks harga saham global berpengaruh terhadap pergerakan IHSG baik positif atau negatif.

\section{Pengaruh Indeks KLCI terhadap IHSG}

Berdasarkan hasil analisi data yang dilakukan oleh peneliti, diketahui bahwa indeks KLCI berpengaruh positif dan signifikan terhadap Indeks Harga Saham Gabungan. Hasil ini sesuai dengan penelitian yang dilakukan oleh Jayanti, et al (2014) yang menyatakan bahwa terdapat pengaruh yang signifikan antara indeks KLCI terhadap Indeks Harga Saham Gabungan. Hubungan positif dan signifikan ini dikarenakan Malaysia secara geografis berdekatan dengan Indonesia dan kedua negara ini berada dalam satu kawasan negara yang saling bekerjasama dalam berbagai bidang yaitu ASEAN.

\section{Pengaruh Indeks Hang Seng terhadap IHSG}

Berdasarkan hasil analisis data yang dilakukan oleh peneliti, diketahui bahwa indeks Hang Seng berpengaruh positif dan tidak signifikan terhadap Indeks Harga Saham Gabungan. Hasil ini sesuai dengan penelitian yang dilakukan oleh Wibowo, et al (2016), dimana dalam penelitiannya menyatakan bahwa indeks Hang Seng tidak memiliki pengaruh yang signifikan terhadap Indeks Harga Saham Gabungan. Hasil penelitian ini menunjukan bahwa variabel Indeks Hangseng tidak berpengaruh signifikan terhadap IHSG. Dengan semakin terintegrasinya perekonomian global dan menyatunya pasar uang beberapa negara dalam wilayah yang berdekatan, ketergantungan ekonomi suatu negara pada ekonomi dunia juga semakin besar. Demikian juga yang terjadi dengan pasar modal suatu negara. Nachrowi 
dan Usman (2006) menjelaskan bahwa pasar modal yang kuat dapat mempengaruhi pasar modal yang lemah. Sebagai salah satu pasar modal yang sedang berkembang, IHSG diduga sangat dipengaruhi indeks pasar saham dunia dan Asia yang berkapitalisasi besar yaitu Hang Seng (bursa saham Hong Kong).

\section{Pengaruh Indeks KOSPI terhadap IHSG}

Berdasarkan hasil analisis data yang dilakukan oleh peneliti, diketahui bahwa indeks KOSPI berpengaruh negatif dan tidak signifikan terhadap Indeks Harga Saham Gabungan. Hasil ini sesuai dengan penelitian yang dilakukan oleh Argamaya (2017) yang menyatakan bahwa adanya pengaruh yang positif dan signifikan antara indeks KOSPI terhadap Indeks Harga Saham Gabungan. Hal ini menunjukkan bahwa perubahan pada indeks KOSPI akan diikuti perubahan pada IHSG yang searah. Hal ini terjadi karena investor yang menanamkan dananya di pasar modal Korea dan Indonesia cenderung adalah investor yang sama.

\section{PENUTUP}

Penelitian ini menguji 5 indeks saham yang memiliki pengaruh terhadap indeks harga saham gabungan. Indeks Nikkei 225 memiliki pengaruh secara negative dan tidak signifikan terhadap IHSG, Strait Times Index memiliki pengaruh secara positif namun tidak signifikan terhadap IHSG, Indeks KLCI berpengaruh secara positif dan signifikan terhadap IHSG, Indeks HangSeng berpengaruh secara positif dan tidak signifikan terhadap IHSG, Indeks KOSPI berpengaruh secara negative dan tidak signifikan terhadap IHSG. Saran yang bisa disampaikan untuk para investor untuk lebih berhati-hati dalam menginvestasikan dana, khususnya di pasar modal. Menganjurkan juga untuk menggunakan variable dependen dan independen yang lain sehingga mampu mendapatkan gambaran yang lebih lengkap mengenai kondisi pasar modal di Indonesia.

\section{DAFTAR PUSTAKA}

Argamaya, Ayu. (2014). Pengaruh Indeks Harga Saham Regional Asia dan Nilai Tukar Mata Uang Terhadap Indeks Harga SahamGabungan (IHSG) di Bursa Efek Indonesia (PERIODE 2009 - 2013).Universitas Bakrie

Astuti, dkk. (2013). Analisis Pengaruh Tingkat Suku Bunga (SBI), Nilai Tukar (Kurs) Rupiah, Inflasi, dan Indeks Bursa Internasional Terhadap IHSG (Studi Pada IHSG di BEI Periode 2008 - 2012). Diponegoro Journal Of Social And Politic Of Science Tahun 2013, Hal 1 - 8.

Chang, Liu. (2009). Regional Integration of Stock Markets in Asia Pacific Countries. Thesis, New York University.

Fajar B.D. (2009). Pengaruh Indeks DJI, FTSE 100, NKY225 dan HSI terhadap Indeks Harga Saham Gabungan Sebelum, Ketika dan Sesudah Subprime Mortgage pada Tahun 2006-2009, Tesis, Magister Manajemen Fakultas Ekonomika dan Bisnis, Universitas Gadjah Mada.

Hasibuan, Ali Fikri dan Taufik Hidayat. (2011). Pengaruh Indeks Harga Saham Global terhadap Pergerakan Indeks Harga Saham Gabungan (IHSG). Jurnal Keuangan dan Bisnis. Vol. 3. No.3. hal. 262-276.

Hidayah, Nurul. (2012). Pengaruh Indeks Bursa Asia Tenggara terhadap Indeks Harga Saham Gabungan di Bursa Efek Indonesia. Jurusan Manajemen, Fakultas Ekonomi, Universitas Gunadarma.

Husted, et al. (2010). International Economics: Eight Edition. New Jersey: Pearson. 
Jayanti, et al. (2014). Pengaruh Tingkat Suku Bunga SBI, Nilai Tukar Rupiah, Indeks Dow Jones dan Indeks KLSE terhadap Indeks Harga Saham Gabungan (Studi pada Bursa Efek Indonesia Periode Januari 2010 - Desember 2013. Jurnal Administrasi Bisnis (JAB) Vol. 11 No. 1 Juni 2014.

Johan, Harun (2007). Analisis Pengaruh Bursa Efek Luar Negeri terhadap Bursa Efek Jakarta. Thesis, Pascasarjana Universitas Diponegoro.

Karim, et al. (2009). Integration of Stock Markets Between Indonesia and Its Major Trading Partners.

Lailia,dkk. (2014). Pengaruh Tingkat Suku Bunga, Tingkat Inflasi, Nilai Kurs Dollar dan Indeks Strait Times terhadap Indeks Harga Saham Gabungan (Studi pada Bursa Efek Indonesia Periode Januari 2010 - Juni 2013. Jurnal Administrasi Bisnis (JAB) Vol. 12 No. 1 Juli 2014.

Lestari, Emilia. (2010). Pengaruh Indeks Nikkei 225, Hang Seng, Kospi, Harga Emas Dunia dan Kurs Rupiah terhadap IHSG Tahun 2005-2010.

Majid,, et al. (2009). Dynamic linkages among ASEAN-5 emerging stock markets. International Journal of Emerging Markets, 4 (2). pp. 160-184. ISSN 1746-8809.

Mansur, Moh. (2005). Pengaruh Indeks Bursa Global terhadap Indeks Harga Saham Gabungan (IHSG) pada Bursa Efek Jakarta(BEJ) Periode Tahun 2000-2002. Sosiohumaniora. Vol. 7. No.3. hal. 203-219.

Pamungkas, Ary Satria. (2010). Analisis Hubungan Indeks Dow Jones, Indeks Hang Seng, Indeks Nikkei, Indeks Strait Times dengan Indeks Harga Saham Gabungan. Jurnal Asy-syukriyyah. Vol.6. hal. 18-31.

Pramudika, Gading. (2013). Pengaruh Indeks Bursa Saham Regional Asia Pasifik terhadap Indeks Harga Saham Gabungan (IHSG) pada Bursa Efek Indonesia (BEI) Periode Tahun 2009-2011. Jurnal Ilmiah Mahasiswa FEB Vol.1, No.2: Semester Genap 2012/2013.

Park, Cyn Young. (2013). Asian Capital Market Integration :Theory and Evidence. Asian Development Bank.

Samsul, M. (2006). Pasar Modal \& Manajemen Portfolio. Jakarta: Erlangga.

Sidiq, Ahmad. (2010). Pengaruh Indeks Saham STI, TAIEX, KOSPI, Hang Seng terhadap Pergerakan Indeks Saham Gabungan pada BEI. Riset Manajemen dan Akuntansi Vol. 1. No.2. Edisi November 2010.

Sugiyono. (2009). Statistika untuk Penelitian. Bandung: Alfabeta.

Suhardianto, Eko. (2012). Analisa Pengaruh Indeks Bursa Saham Dunia terhadap Indeks Harga Saham Gabungan Bursa Efek Indonesia Periode 2005-2011. Yogyakarta : Universitas Gadjah Mada.

Tamara, S.F. (2013). Pengaruh Dow Jones Industrial Average, Deutscher Aktienindex, Shanghai Stock Exchange Composite Index, dan Straits Times Index Terhadap Indeks Harga Saham Gabungan di Bursa Efek Indonesia (Periode 2010 - 2012). Malang: Universitas Brawijaya.

Tongku, Christopher. (2013). Stock Market Integration between Indonesia and Malaysia. Calyptra: Jurnal Ilmiah Mahasiswa Universitas Surabaya Vol. 2. No. 2.

Wibowo, et al. (2016). Analisis Pengaruh Tingkat Inflasi, Suku Bungan SBI, Nilai Tukar US Dollar pada Rupiah, Jumlah Uang Beredar, Indeks Dow Jones, Indeks Nikkei 225, dan Indeks Hangseng Terhadap Pergerakan Indeks Harga Saham Gabungan (IHSG) (Periode 2010-2014). Journal Of Accounting, Volume 2 No.2 Maret 2016. Yogyakarta: Universitas Islam Negeri Sunan Kalijaga.

Widodo, (2017). Analisi Pengaruh Indeks Harga Saham Gabungan Regional Asia Terhadap Indeks Harga Saham Gabungan Indonesia.

Wijayanti, Anis. (2013). Pengaruh Beberapa Variabel Makro Ekonomi dan Indeks Pasar 
Modal Dunia terhadap Pergerakan Indeks Harga Saham Gabungan (IHSG) di BEI. Fakultas Ekonomi Universitas Brawijaya.

Witjaksono, A.A . (2010). Analisis Pengaruh Tingkat Suku Bunga SBI, Harga Minyak Dunia, Harga Emas Dunia, Kurs Rupiah, Indeks Nikkei 225, dan Indeks Dow Jones terhadap IHSG (studi kasus pada IHSG di BEI selama periode 2000-2009). Fakultas Ekonomi, Universitas Diponegoro.

Wong, et al. (2004). The Relationship Between Stock Markets of Major Developed Countries and Asian Emerging Markets. Journal of Applied Mathematics and Decision Sciences, Vol.8, pp. 201-218.

www.investing.com

yahoo.finance.com 